\title{
Role of Balanitoside on Hyperglycemia and Oxidative Stress in Diabetic Rats
}

\author{
Wusa Makena ${ }^{1}$, Wilson Oliver Hamman ${ }^{1}$, Adebayo Adekunle Buraimoh ${ }^{2}$ and Nathan Isaac Dibal ${ }^{3 *}$ \\ ${ }^{1}$ Department of Human Anatomy, Ahmadu Bello University Zaria, Nigeria \\ ${ }^{2}$ Department of Human Anatomy, Kaduna State University, Nigeria \\ ${ }^{3}$ Department of Human Anatomy, University of Maiduguri, Nigeria
}

*Corresponding author: Nathan Isaac Dibal, Department of Human Anatomy, University of Maiduguri, PMB 1069 Maiduguri, Borno State, Nigeria, Tel: +2348069088308; Email: nathandibal@gmail.com

Submission: 監 August 08, 2018; Published: 眥 October 15, 2018

\begin{abstract}
The aim of the study was to evaluate the effect of Balanitoside on hyperglycemia, pancreatic $\beta$-cells and oxidative stress in diabetic rats. Eighty diabetic rats were divided into four groups of twenty rats each; group I serve as diabetic control and receive distilled water at $0.5 \mathrm{mg} / \mathrm{kg}$, groups II-IV serve as the experimental groups and receive $10 \mathrm{mg} / \mathrm{kg}, 20 \mathrm{mg} / \mathrm{kg}$ of Balatinoside and 6units $/ \mathrm{kg}$ of Insulin respectively. Group V serve as the normal control and consist of twenty non-diabetic rats, they were given distilled water at $0.5 \mathrm{mg} / \mathrm{kg}$. Five rats from each group were sacrificed on day $8,15,22$ and 29, the fasting blood glucose levels were monitored on weekly basis. The liver and pancreas were dissected; the liver was homogenized in Phosphate buffer Saline, centrifuged at $5000 \mathrm{x}$ g and used to determine the activities of CAT, SOD and GSH. The pancreas was processed for light microscopic study and stained with H\&E and Gomori Aldehyde. The result showed significant reduction in the fasting blood glucose levels of rats treated with Balanitoside and insulin as compared to those of diabetic control $(\mathrm{P}<0.05)$, a significant increase in CAT, SOD \&GSH levels were observed in rats treated with Balanitoside and insulin as compared with those of diabetic control rats $(\mathrm{P}<0.05)$. Regeneration of pancreatic $\beta$-cells was observed in rats treated with Balanitoside and insulin. In conclusion, Balanitoside decrease blood glucose levels and oxidative stress in diabetic rats and cause the regeneration of pancreatic $\beta$-cells.
\end{abstract}

Keywords: Balanitoside; Diabetes; Hyperglycemia; Oxidative stress; $\beta$-cells

\section{Introduction}

Diabetes mellitus (DM) is a chronic disorder characterized by high blood glucose level either as a result of reduction or lack of insulin production or the body's ineffective use of insulin [1]. DM can be classified into two main categories: type 1 that occurs because of immune destruction of pancreatic $\beta$-cells leading to decrease/ lack of insulin production and type 2 that occur as a result of tissue insulin resistance characterized by high blood glucose level with normal insulin production [2]. As the need for insulin increases, the pancreas loses its ability to produce insulin leading to relative insulin deficiency [3]. Type 2 diabetes in known to have a strong genetic influence with contributing environmental factor, other contributing factors includes age, sedentary lifestyle, distribution of fat and obesity [4]. Globally, DM is a major health problem and one of the most prevalent endocrine disorder. According to international diabetes federation (IDF), about 382 million people were suffering from diabetes in 2013 and there is an expected increase to 592 million in 2035 [5,6]. Complications of DM includes; cardiomyopathy, dyslipidemia, neuropathy, nephropathy and retinopathy $[7,8]$. DM can be managed or controlled by either adjusting diet with regular exercise, insulin replacement therapy or the use of oral hypoglycemic drugs [7]. Oxidative stress occurs as a result of reduction in antioxidant capacity which can increase the dele terious effects of free radicals and consequently lead to the development of diabetes complications [9]. Antioxidants scavenge free radicals and peroxides formed during oxidative stress that occur due to disease [10]. Due to the high cost of insulin and most oral hypoglycemic drugs and the side effects associated with their use, there are still challenges in the management of diabetes without side effects $[8,11]$. Therefore, there is a need for a novel diabetic drug with less or no side effects [12]. The role of many plant extract in the management of diabetes suggest that plants phytochemicals may play important role in drug development. Previous studies revealed that the hypoglycemic effects of most medicinal plants are attributed to their saponin content [13-15]. Balanitosides are saponin from Balanite aegyptiaca fruit, they belong to a large family of structurally related compounds of steroid or triterpenoid aglycone (sapogenin) linked to one or more oligo saccharide moieties by glycosidic linkage, the carbohydrate moiety consists of pentoses, hexoses, or uronic acids. The presence of both polar (sugar) and no polar (steroid or triterpene) groups provide saponins with strong surface-active properties which distinguish these compounds from other glycosides [16]. The aim of the study was to evaluate the effect of Balanitoside on hyperglycemia, pancreatic $\beta$-cells and oxidative stress markers in diabetic rats. 


\section{Materials and Methods}

\section{Plant material}

The fruit of Balanite aegyptiaca were purchased from a local market in Guyuk Local Government of Adamawa State, Nigeria. Identification and authentication of the fruit was done at Herbarium Unit, Department of Biological Sciences, Ahmadu Bello University (ABU) Zaria, Nigeria. Voucher number 2064.

Wistar rats of both sexes weighing between 150-200g were obtained from the Animal House, Department of Pharmacology and Therapeutics, ABU, Zaria. They were fed with grower mash feed (Vital Feeds, Grand cereal, Jos, Nigeria.) and provided with water ad libitum. They were acclimatize to the animal house conditions two (2) weeks prior to commencement of the experiment. The research was approved by ABU Zaria research and ethical committee, it was in conformity with the ARRIVE guidelines (reporting of in vivo experiment) and was carried out in accordance with the National Institutes of Health Guide for the Care and Use of Laboratory Animals.

\section{Balanitoside extraction}

The coat of Balanite aegyptiaca fruit was gently removed the mesocarp (fleshy part) was peeled and air dried at room temperature and grounded into powdered. The powdered mesocarp was defatted by petroleum ether $3 \times 1 \mathrm{~h}$ at $40^{\circ} \mathrm{C}$. Balanitoside was isolated from Balanite aegyptiaca fruits using a procedure described by Wiart et al. [17], powdered fruits from Balanite aegyptiaca was extracted with petroleum ether ( 3 times with $1.5 \mathrm{~L}$ ) over 3 days with shaking at ambient temperature and the combined extracts filtered. Then the precipitate extracted with methelene chloride (3 times with $1.5 \mathrm{~L}$ ) over 3 days with shaking at ambient temperature and the combined extracts filtered then the precipitate extracted with ethyl acetate ( 3 times with 1.5L) over 3 days with shaking at ambient temperature and the combined extracts filtered. The precipitate extracted with methylene chloride ( 3 times with $1.5 \mathrm{~L}$ ) over 3 days with shaking at ambient temperature and the combined extracts filtered the precipitate extracted with butanol ( 3 times with $1.5 \mathrm{~L}$ ) over 3 days with shaking at ambient temperature and the combined extracts filtered and evaporated to dryness in a rotary evaporator under reduced pressure.

\section{Tests for saponins}

Saponins was identified according to the method described by Ayoola et al. [18] where $0.5 \mathrm{~g}$ of extract was added $5 \mathrm{ml}$ of distilled water in a test tube. The solution was shaken vigorously and observed for a stable persistent froth. The frothing was mixed with 3 drops of olive oil and shaken vigorously after which it was observed for the formation of an emulsion. Also Foam test was applied according to the method described by Arulpriya et al. [19] where Crude extract was mixed with $5 \mathrm{ml}$ of distilled water in a test tube and it was shaken vigorously, and some drops of olive oil was add. The formation of stable foam was taken as an indication for the presence of saponins.

\section{Induction of hyperglycemia}

Hyperglycemia was induced using streptozotocin freshly prepared in $0.1 \mathrm{M}$ of citrate buffer $(\mathrm{pH} 4.5)$ according to the method described by Al Attar et al. [20]. The rats were fasted over night with free access to water prior to the induction of hyper glycemia which was carried out by a single intra-peritoneal injection of the steptozotocin at $50 \mathrm{mg} / \mathrm{kg}$ body weight. After 72 hours of streptozotocin administration, blood was collected from the tail vein of the rats and the blood Glucose concentration were measured with digital glucometer and strips (Accu-Chek $®$ Advantage, Roche Diagnostic, Germany). Rats having fasting blood glucose concentration above $250 \mathrm{mg} / \mathrm{dL}$ were considered hyperglycemic and selected for the study. The rats were then allowed to stabilize with consistent hyperglycemia for another 15 days before the research.

\section{Experimental design}

Eighty (80) diabetic rats were divided into four groups of twenty rats each; group I serve as the diabetic control and receive distilled water through intra-peritoneal injection at $0.5 \mathrm{mg} / \mathrm{kg}$, groups II-IV serve as the experimental groups and receive $10 \mathrm{mg} / \mathrm{kg}$, $20 \mathrm{mg} / \mathrm{kg}$ body weight of Balatinoside and 6units/kg body weight of Insulin respectively through intra-peritoneal injection. Group V serve as the normal control and consist of twenty (20) non-diabetic rats, they were given distilled water at $0.5 \mathrm{mg} / \mathrm{kg}$. Five rats from each group were sacrificed on day 8 (week 1), day 15 (week 2), day 22 (week 3) and day 29 (week 4). The fasting blood glucose levels of each rat was monitored, the liver of all the rats were dissected out, homogenized in Phosphate buffer Saline ( $\mathrm{pH}$ 7.4) using a Teflon homogenizer. The homogenate was then centrifuged at 5,000 $\mathrm{x}$, the supernatant was used to determine the activities of oxidative stress markers i.e. Catalase (CAT) Superoxide Dismutase (SOD) and Glutathione reductase (GSH). The pancreas of rats were dissected out on the $29^{\text {th }}$ day, fixed in neutral buffered formalin (NBF), dehydrated in graded series of alcohol, embedded in paraffin wax, cleared in xylene, sectioned at $5 \mu \mathrm{m}$ using a rotary microtome and stained with Heamatoxylin and eosin (H\&E) and Gomori Aldehyde.

\section{Statistical analysis}

The data were analyzed with statistical package for social science (SPSS) version 20 (IBM, USA), one-way analysis of variance (ANOVA) and Turkey post hoc test were used to compare the differences between and within groups. All the data were expressed as Mean \pm standard deviation (SD) and $\mathrm{P}<0.05$ was considered statistically significant.

\section{Results}

There was a significant reduction in the fasting blood glucose levels of rats treated with $10 \mathrm{mg} / \mathrm{kg} \& 20 \mathrm{mg} / \mathrm{kg}$ Balanitoside and 6units/kg insulin as compared to those of diabetic control rats in all the weeks at $\mathrm{P}<0.05$, There was no significant difference in the fasting blood glucose levels between the normal control rats and rats treated with Balanitoside and insulin $(\mathrm{P}>0.05)$, see Table 1. 
Table 1: Fasting blood glucose levels (mg/dL) of diabetic and non-diabetic rats treated with Balanitoside and insulin.

\begin{tabular}{|c|c|c|c|c|c|}
\hline Week & Diabetic Control & $\begin{array}{c}\mathbf{1 0 m g} / \mathbf{k g} \\
\text { Balanitoside }\end{array}$ & $\begin{array}{c}\mathbf{2 0 m g} / \mathbf{k g} \\
\text { Balanitoside }\end{array}$ & $\begin{array}{c}\text { 6units/kg } \\
\text { Insulin }\end{array}$ & Normal Control \\
\hline 1 & $435.00 \pm 76.41^{\mathrm{b}}$ & $132.20 \pm 10.21^{\mathrm{a}}$ & $141.40 \pm 56.59^{\mathrm{a}}$ & $171.60 \pm 45.39^{\mathrm{a}}$ & $106.40 \pm 12.42^{\mathrm{a}}$ \\
\hline 2 & $517.60 \pm 52.32^{\mathrm{b}}$ & $131.40 \pm 11.63^{\mathrm{a}}$ & $158.20 \pm 17.02^{\mathrm{a}}$ & $145.40 \pm 40.00^{\mathrm{a}}$ & $110.80 \pm 12.56^{\mathrm{a}}$ \\
\hline 3 & $532.80 \pm 34.49^{\mathrm{c}}$ & $106.20 \pm 10.52^{\mathrm{ab}}$ & $142.20 \pm 27.19^{\mathrm{b}}$ & $97.60 \pm 11.42^{\mathrm{a}}$ & $110.60 \pm 10.28^{\mathrm{ab}}$ \\
\hline 4 & $547.80 \pm 40.00^{\mathrm{b}}$ & $112.60 \pm 7.50^{\mathrm{a}}$ & $129.20 \pm 7.29^{\mathrm{a}}$ & $109.80 \pm 18.17^{\mathrm{a}}$ & $102.40 \pm 8.32^{\mathrm{a}}$ \\
\hline
\end{tabular}

Values expressed as Mean \pm SD. Values along the same row with different superscripts a,b,c and d are significantly different $(\mathrm{P}<0.05)$

A significant increase in CAT levels was observed in rats treated with Balanitoside at $10 \mathrm{mg} / \mathrm{kg} \& 20 \mathrm{mg} / \mathrm{kg}$ and $6 \mathrm{units} / \mathrm{kg}$ insulin as compared with those of diabetic control rats $(\mathrm{P}<0.05)$ in week 2. There was no significant difference in CAT levels between diabetic control rats and rats treated with $20 \mathrm{mg} / \mathrm{kg}$ Balanitoside and 6units/kg insulin in weeks 3 and 4 with no significant change between the CAT levels of normal control rats and rats treated with $10 \mathrm{mg} / \mathrm{kg}$ Balanitoside and 6units/kg insulin in weeks 1, 2, and 3 $(\mathrm{P}>0.05)$, see Table 2 .

Table 2: CAT levels $(\mu / \mathrm{mg})$ of diabetic and non-diabetic rats treated with and Balanitoside and insulin.

\begin{tabular}{|c|c|c|c|c|c|}
\hline Week & Diabetic Control & $\begin{array}{c}\mathbf{1 0 m g} / \mathbf{k g} \\
\text { Balanitoside }\end{array}$ & $\begin{array}{c}\mathbf{2 0} \mathbf{m g} / \mathbf{k g} \\
\text { Balanitoside }\end{array}$ & $\begin{array}{c}\mathbf{6 u n i t s} / \mathbf{k g} \\
\text { insulin }\end{array}$ & Normal Control \\
\hline 1 & $44.30 \pm 9.61^{\mathrm{a}}$ & $50.88 \pm 10.24^{\mathrm{ab}}$ & $51.61 \pm 3.97^{\mathrm{b}}$ & $48.52 \pm 2.89^{\mathrm{ab}}$ & $57.53 \pm 6.05^{\mathrm{b}}$ \\
\hline 2 & $36.71 \pm 3.38^{\mathrm{a}}$ & $53.20 \pm 3.55^{\mathrm{cd}}$ & $50.40 \pm 4.09^{\mathrm{bc}}$ & $45.92 \pm 3.64^{\mathrm{b}}$ & $57.40 \pm 3.39^{\mathrm{d}}$ \\
\hline 3 & $34.27 \pm 12.09^{\mathrm{a}}$ & $44.18 \pm 13.17^{\mathrm{b}}$ & $40.30 \pm 5.51^{\mathrm{ab}}$ & $41.82 \pm 9.47^{\mathrm{ab}}$ & $57.98 \pm 0.61^{\mathrm{b}}$ \\
\hline 4 & $32.23 \pm 5.99^{\mathrm{a}}$ & $40.48 \pm 2.73^{\mathrm{a}}$ & $41.70 \pm 10.27^{\mathrm{a}}$ & $36.06 \pm 6.54^{\mathrm{a}}$ & $57.18 \pm 3.45^{\mathrm{b}}$ \\
\hline
\end{tabular}

CAT: Catalase Values expressed as Mean \pm SD. Values along the same row with different superscripts a,b,c and $d$ are significantly different $(\mathrm{P}<0.05)$

There was a significant increase in the SOD levels of rats treated with $10 \mathrm{mg} / \mathrm{kg} \& 20 \mathrm{mg} / \mathrm{kg}$ Balanitoside and 6units $/ \mathrm{kg}$ insulin as compared with the diabetic control rats in weeks $1,2 \& 4(\mathrm{P}<0.05)$ with no significant change between diabetic control rats and rats treated with $10 \mathrm{mg} / \mathrm{kg} \& 20 \mathrm{mg} / \mathrm{kg}$ Balanitoside and 6units $/ \mathrm{kg}$ insulin in week $3(\mathrm{P}>0.05)$. A significant reduction in SOD levels were observed in rats treated with $10 \mathrm{mg} / \mathrm{kg} \& 20 \mathrm{mg} / \mathrm{kg}$ Balanitoside and 6units $/ \mathrm{kg}$ insulin as compared with the normal control rats in weeks $3 \& 4(\mathrm{P}<0.05)$. There was no significant difference in SOD levels between normal control rats and rats treated with $10 \mathrm{mg} / \mathrm{kg}$ $\& 20 \mathrm{mg} / \mathrm{kg}$ Balanitosidein weeks 1 \& $2(\mathrm{P}>0.05)$ see Table 3.

Table 3: SOD leve $1(\mu \mathrm{g} / \mathrm{ml})$ of diabetic and non-diabetic rats treated with and Balanitoside and insulin.

\begin{tabular}{|c|c|c|c|c|c|}
\hline Week & Diabetic Control & $\begin{array}{c}\mathbf{1 0 m g} / \mathbf{k g} \\
\text { Balanitoside }\end{array}$ & $\begin{array}{c}\text { 20mg/kg } \\
\text { Balanitoside }\end{array}$ & $\begin{array}{c}\text { 6units/kg } \\
\text { Insulin }\end{array}$ & $1.51 \pm 0.09^{\mathrm{b}}$ \\
\hline 1 & $0.98 \pm 0.33^{\mathrm{a}}$ & $1.75 \pm 0.18^{\mathrm{b}}$ & $1.54 \pm 0.21^{\mathrm{b}}$ & $1.78 \pm 0.08^{\mathrm{b}}$ \\
\hline 2 & $0.97 \pm 0.27^{\mathrm{a}}$ & $1.80 \pm 0.09^{\mathrm{bc}}$ & $1.73 \pm 0.14 \mathrm{~b}^{\mathrm{c}}$ & $0.93 \pm 0.33^{\mathrm{a}}$ & $1.87 \pm 0.07^{\mathrm{c}}$ \\
\hline 3 & $0.92 \pm 0.23^{\mathrm{a}}$ & $1.13 \pm 0.12^{\mathrm{a}}$ & $1.05 \pm 0.11^{\mathrm{a}}$ & $1.82 \pm 0.12^{\mathrm{b}}$ \\
\hline 4 & $0.80 \pm 0.12^{\mathrm{a}}$ & $1.10 \pm 0.10^{\mathrm{b}}$ & $1.04 \pm 0.20^{\mathrm{ab}}$ & $1.37 \pm 0.06^{\mathrm{c}}$ & $1.82 \pm 0.12^{\mathrm{d}}$ \\
\hline
\end{tabular}

SOD: Superoxide Dismutase Values expressed as Mean \pm SD. Values along the same row with different superscripts a,b,c and $\mathrm{d}$ are significantly different $(\mathrm{P}<0.05)$.

A significant increase in GSH level was observed in rats treated with $10 \mathrm{mg} / \mathrm{kg} \& 20 \mathrm{mg} / \mathrm{kg}$ Balanitoside and 6 units/kg insulin as compared with the diabetic control rats in week $1(\mathrm{P}<0.05)$ with no significant change between diabetic control and rats treated with $20 \mathrm{mg} / \mathrm{kg}$ Balanitoside and 6units/kg insulin in weeks 2, 3 \&
4 ( $>>0.05)$. There was a significant increase in GSH levels of rats treated with Balanitoside at $10 \mathrm{mg} / \mathrm{kg}$ as compared with diabetic control rats in weeks $2,3 \& 4(\mathrm{P}<0.05)$ with no significant change between those of normal control rats and rats treated with Balanitoside at $10 \mathrm{mg} / \mathrm{kg}$ in all the weeks $(\mathrm{P}>0.05)$, see Table 4 . 
Table 4: GSH levels $(\mu \mathrm{g} / \mathrm{ml})$ of diabetic and non-diabetic rats treated with and Balanitoside and insulin.

\begin{tabular}{|c|c|c|c|c|c|}
\hline Week & Diabetic Control & $\mathbf{1 0} \mathbf{m g} / \mathbf{k g}$ Balanitoside & $\mathbf{2 0} \mathbf{m g} / \mathbf{k g}$ Balanitoside & $\mathbf{6 u n i t s} / \mathbf{k g}$ insulin & Normal Control \\
\hline 1 & $14.33 \pm 1.19^{\mathrm{a}}$ & $27.12 \pm 5.59^{\mathrm{bc}}$ & $20.68 \pm 1.89^{\mathrm{b}}$ & $20.50 \pm 3.32^{\mathrm{b}}$ & $28.18 \pm 3.92^{\mathrm{c}}$ \\
\hline 2 & $17.27 \pm 1.64^{\mathrm{a}}$ & $25.59 \pm 4.32^{\mathrm{b}}$ & $21.26 \pm 4.31^{\mathrm{ab}}$ & $18.25 \pm 1.23^{\mathrm{a}}$ & $24.28 \pm 1.34^{\mathrm{b}}$ \\
\hline 3 & $17.4 \pm 1.39^{\mathrm{a}}$ & $25.85 \pm 7.17^{\mathrm{b}}$ & $21.54 \pm 1.67^{\mathrm{b}}$ & $19.26 \pm 2.54^{\mathrm{ab}}$ & $25.31 \pm 1.88^{\mathrm{b}}$ \\
\hline 4 & $16.79 \pm 2.83^{\mathrm{ab}}$ & $21.81 \pm 0.77^{\mathrm{bc}}$ & $18.67 \pm 3.61^{\mathrm{ab}}$ & $16.14 \pm 3.15^{\mathrm{a}}$ & $24.62 \pm 2.62^{\mathrm{c}}$ \\
\hline
\end{tabular}

GSH: Glutathione Reductase Values expressed as Mean \pm SD. Values along the same row with different superscripts a,b,c and $\mathrm{d}$ are significantly different $(\mathrm{P}<0.05)$.

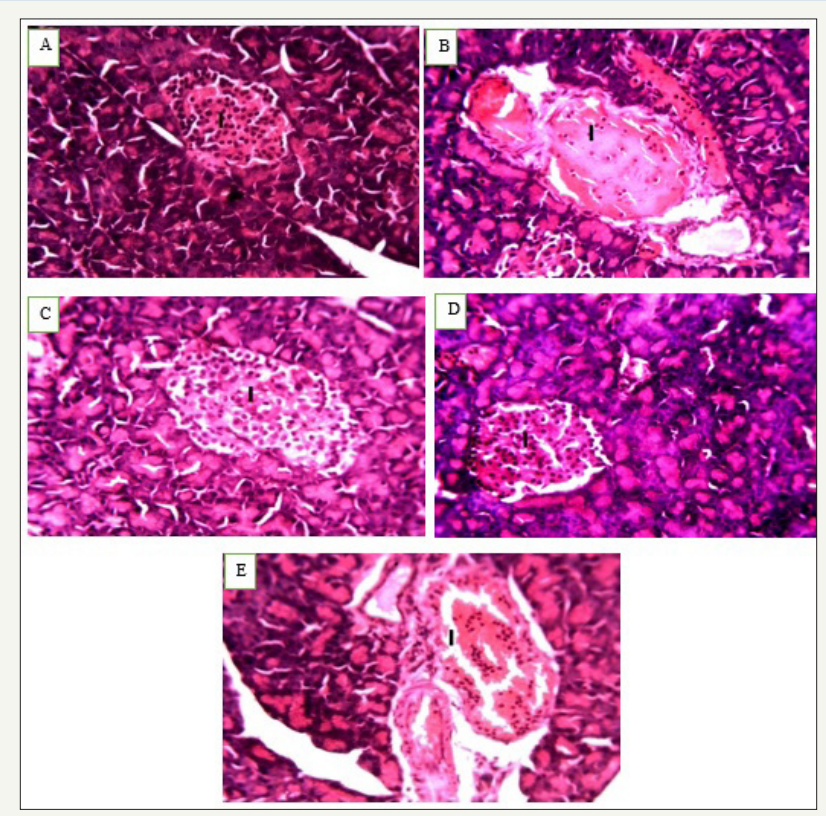

Figure 1: Photomicrograph of pancreas of normal control rats A, diabetic control rats B, rats treated with Balanitoside at $10 \mathrm{mg} / \mathrm{kg} \mathrm{C}$, and $20 \mathrm{mg} / \mathrm{kg} \mathrm{D}$, and rats treated with 6units $/ \mathrm{kg}$ insulin E, showing pancreatic islets I with $\beta$-cells. H \& E stain $\mathrm{X} 250$.

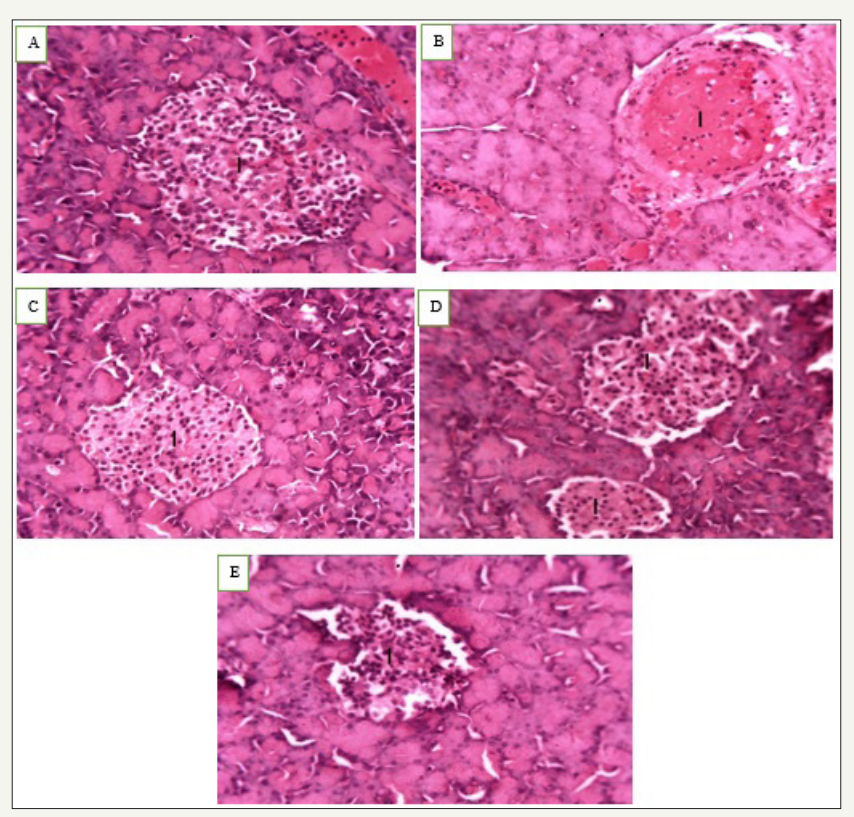

Figure 2: Photomicrograph of pancreas of normal control rats A, diabetic control rats B, rats treated with Balanitoside at $10 \mathrm{mg} / \mathrm{kg} \mathrm{C}$, and $20 \mathrm{mg} / \mathrm{kg} \mathrm{D}$, and rats treated with 6units $/ \mathrm{kg}$ insulin E, showing pancreatic islets I with $\beta$-cells. Gomori Aldehyde Fulchsin Stain X250. 
The photomicrograph of pancreas of normal control rats showed normal architecture of the pancreas with normal $\beta$-cell Figure $1 \mathrm{~A} \& 2 \mathrm{~A}$, photomicrograph of diabetic control rats showed degeneration of pancreatic $\beta$-cells Figure $1 B$ \& $2 B$ photomicrograph of rats treated with Balanitoside at $10 \mathrm{mg} / \mathrm{kg} \& 20 \mathrm{mg} / \mathrm{kg}$ showed regeneration of pancreatic $\beta$-cells (Figure 1C, 1D, 2C \& 2D) while the photomicrograph of pancreas of rats treated with 6 units $/ \mathrm{kg}$ insulin showed regeneration of the pancreatic $\beta$-cells with intercellular Figure 1E \& 2E.

\section{Discussion}

The significant decrease in the fasting blood glucose levels of rats treated with Balanitoside in all the weeks is an indication that Balanitoside at $10 \mathrm{mg} / \mathrm{kg}$ and $20 \mathrm{mg} / \mathrm{kg}$ is capable of treating hyperglycemia. However, 6unit/kg insulin gave a better effect than Balanitoside, these agrees with earlier study [21] which showed an association between higher incidences of hypoglycemia with intensive diabetes treatment. The possible mechanisms through which Balanitoside brings about its anti-hyperglycemic action in diabetic rats may be by potentiating the insulin effect of plasma from the existing B-cells or by its release from the bound form. The significant increase in the levels of CAT, SOD and GSH in rats treated with Balanitoside at $10 \mathrm{mg} / \mathrm{kg}$ and $20 \mathrm{mg} / \mathrm{kg}$ is an indication that Balanitoside can increase the activities of oxidative stress markers by scavenging free radicals to reduce oxidative stress that usually occur because of diabetes mellitus. The non-significant difference in the levels of CAT, SOD and GSH between rats treated with Balanitoside at $10 \mathrm{mg} /$ $\mathrm{kg}$ and $20 \mathrm{mg} / \mathrm{kg}$ and 6 units/ $\mathrm{kg}$ insulin shows that Balanitoside is as effective as insulin in scavenging free radicals. CAT, SOD and GSH are crucial cellular components of the body's antioxidant defense system. Thus, they play an important role in the maintenance of a balanced redox status [10]. SOD maintains the cellular levels of $\mathrm{O}_{2}{ }^{-}$ by converting $\mathrm{O}_{2}^{-{ }^{-}}$to $\mathrm{H}_{2} \mathrm{O}_{2}$, a more stable reactive oxygen species (ROS) while CAT and GSH metabolizes $\mathrm{H}_{2} \mathrm{O}_{2}$ to $\mathrm{O}_{2}$ and $\mathrm{H}_{2}$ O. [22] Earlier studies showed that over expression of antioxidant enzymes in islets or transgenic mice and antioxidants such as N-acetyl-Lcysteine (NAC) protect against ROS-induced $\beta$-cell toxicity [23]. The increase in the activities of oxidative stress markers that occur as a result of Balanitoside is more in weeks $1 \& 2$ as compare to weeks $3 \& 4$; this might be due to increase in unstable ROS with the progress of diabetes that will require more antioxidant to reduce the oxidative stress [24,25].

The degeneration/degranulation of pancreatic $\beta$-cells of diabetic control rats showed that streptozotocin is capable of inducing hyperglycemia by destroying pancreatic $\beta$-cells $[26,27]$. The regeneration of pancreatic $\beta$-cells in rats treated with Balanitoside suggest the presence of stable cells in the islets with the ability of regenerating $\beta$-cells [28]. This also suggests that Balanitoside at $10 \mathrm{mg} / \mathrm{kg}$ and $20 \mathrm{mg} / \mathrm{kg}$ has the ability of inducing the quiescent cells to proliferate and replace the lost cells; The antioxidant properties of Balanitoside may have stopped further destruction of the remaining $\beta$-cells by mopping up the circulating ROS generated by the Streptozotocin and then allowing the Balanitoside to induce regenerative activities.

\section{Conclusion}

The present study showed that Balanitoside is capable of decreasing blood glucose level of diabetic rats by preventing further destruction of pancreatic $\beta$-cells as a result of streptozotocin action and increasing the activities of oxidative stress markers (SOD, GSH and CAT) leading to decrease in oxidative stress.

\section{Author' contribution}

Conception and design: WM, WOH \& AAB, Administrative support: WOH \& AAB, Provision of study materials: WM \& NID, Collection and assembly of data: WM \& NID, Data analysis and interpretation: All authors, Manuscript writing: All authors, Final approval of manuscript: All authors.

\section{References}

1. World Health Organization (2018) Global report on diabetes.

2. American Diabetes Association (2013) Diagnosis and classification of diabetes mellitus. Diabetes Care 33 (Suppl 1): S62-S9.

3. Cunha AP, Ribeiro AB, Ricardo NS, Oliveira AC, Davila LP, et al. (2017) Polysaccharides from Caesalpinia ferrea seeds-chemical characterization and antidiabetic effects in Wistar rats. Food Hydrocolloids 65: 6876.

4. Dey L, Attele SA, Yuan C (2002) Alternative therapies for type 2 diabetes. Altern Med Rev 7(1): 45-58.

5. Guariguata L, Whiting DR, Hambleton I, Beagley J, Linnenkamp U, et al. (2014) Global estimates of diabetes prevalence for 2013 and projections for 2035. Diabetes Res Clin Pract 103(2): 137-149.

6. Réggami Y, Berredjem H, Cheloufi H, Berredjem M, Bouzerna N (2016) Antihyperglycemic and antidiabetic effects of Ethyl (S)-2-(1-cyclohexylsulfamide carbamoyloxy) propanoate in streptozotocin-induced diabetic Wistar rats. European J Pharmacol 779: 122-130.

7. Elekofehinti 00 (2015) Saponins: Anti-diabetic principles from medicinal plants - A review. Pathophysiol 22(2): 95-103.

8. Wannes WA, Marzouk B (2016) Research progress of Tunisian medicinal plants used for acute diabetes. Journal of Acute Disease 5(5): 357-363.

9. Baynes JW (1991) Role of oxidative stress in development of complications in diabetes. Diabetes 40(4): 405-412.

10. Evan G, Littlewood TA (1998) Matter of life and cell death. Science 281(5381): 1317-1322.

11. Meliani N, Dib ME, Allali H, Tabti B (2011) Hypoglycemic effect of Berberis vulgaris $\mathrm{L}$. in normal and streptozotocin-induced diabetic rats. Asian Pac J Trop Biomed 1(6): 468-471.

12. Nathan DM, Buse JB, Davidson MB, Ferrannini E, Holman RR, et al. (2009) Medical management of hyperglycemia in type 2 diabetes: a consensus algorithm for the initiation and adjustment of therapy. Diabetes Care 32(1): 193-203.

13. Neto MCL, Vasconcelos D, Thijan VN, Caldas GFR, Araújob AV, et al. (2013) Evaluation of anti hyperglycaemic activity of Calotropis procera leaves extract on streptozotocin-induced diabetes in Wistar rats. Rev Bras Farmacogn 23(6): 913-919.

14. Chandramohan R, Pari L (2016) Anti-inflammatory effects of tyrosol in streptozotocin-induced diabetic Wistar rats. J Function Foods 27: 17-28.

15. Balogun FO, Ashafa AO (2017) Aqueous root extracts of Dicoma anomala (Sond.) extenuates postprandial hyperglycaemia in vitro and its modulation on the activities of carbohydrate-metabolizing enzymes in streptozotocin-induced diabetic Wistar rats. South African Journal of Botany 112: 102-111. 
16. Yu FC, Chao HY, Ming SC, Yong Ping C, Yu Chun H (2010) Foam properties and detergent abilities of the Saponins from Camellia oleifera. Intr J Mole Sci 11(11): 4417-4425.

17. Wiart C, Hannah A, Yassim M, Hamimah H, Sulaiman M (2004) Antimicrobial activity of Acalypha siamensis Oliv. ex Gage. J Ethnopharmacol 95(2-3): 285-286.

18. Ayoola GA, Coker HA, Adesegun SA, Adepoju AA, Obaweya K, et al. (2008) Phytochemical screening and antioxidant activities of some selected medicinal plants used for malaria therapy in southwestern Nigeria. Tropical J Pharmaceut Res 7(3): 1019-1024.

19. Arulpriya P, Lalitha P, Hemalatha S (2010) Cyclic voltammetric assessment of the antioxidant activity of petroleum ether extract of Samaneasaman (Jacq) Merr Advan Applied Sci Res 1: 24-35.

20. Al Attar AM, Zari TA (2007) Modulatory effects of ginger and clove oils on physiological responses in streptozotocin-induced diabetic rats. Intr J Pharmacol 3(1): 34-40.

21. Ismail F, Craven T, Banerji MA, Basile J, Calles J, et al. (2010) Effect of intensive treatment of hyperglycemia on microvascular outcomes in type 2 diabetes: an analysis of the ACCORD randomized trial. Lancet 376(9739): 419-430.

22. Halliwell B, Gutteridge JM (2007) Free radicals in biology and medicine ( $4^{\text {th }}$ edn), Clarendon Press, Oxford, USA.
23. Drews G, Krippeit P, Dufer M (2010) Oxidative stress and beta-cell dysfunction. Pflugers Arch 460(4): 703-718.

24. Yang Z, Laubach VE, French BA, Kron IL (2009) Acute hyperglycemia enhances oxidative stress and exacerbates myocardial infarction by activating nicotinamide adenine dinucleotide phosphate oxidase during reperfusion. J Thorac Cardiovasc Surg 137(3): 723-729.

25. Tsuruta R, Fujita M, Ono T, Koda Y, Koga Y, et al. (2010) Hyperglycemia enhances excessive superoxide anion radical generation, oxidative stress, early inflammation, and endothelial injury in forebrain ischemia/ reperfusion rats. Brain Res 14(1309): 155-163.

26. Standl E, Lang H, Roberts A (2003) The 12-month efficacy and safety of insulin detemir and NPH insulin in basal-bolus therapy for the treatment of type 1 diabetes. Diabetes Technol Ther 6(5): 579-588.

27. Bathina S, Srinivas N, Das UN (2017) Streptozotocin produces oxidative stress, inflammation and decreases BDNF concentrations to induce apoptosis of RIN5F cells and type 2 diabetes mellitus in Wistar rats. Biochem Biophys Res Comm 486(2): 406-413.

28. Lukacinova A, Mojzis J, Benacka R, Keller J, Maguth T, et al. (2008) Preventive effects of flavonoids on alloxan-induced diabetes mellitus in rats. Acta Vet Brno77: 175-182.

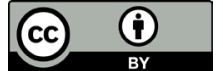

Creative Commons Attribution 4.0 International License

For possible submissions Click Here

\section{Submit Article}

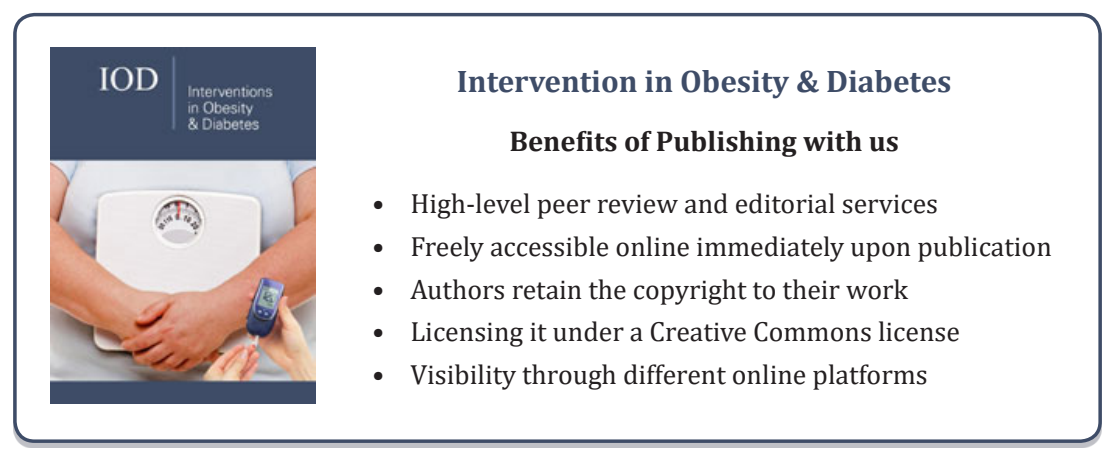

